\title{
IMPLEMENTATION OF MOTOR DEVELOPMENT CHARACTERISTICS IN SEPAK TAKRAW TRAINING
}

\author{
Abdul Aziz Hakim* Achmad Sofyan Hanif** \\ State University of Surabaya* \\ State University of Jakarta** \\ aahakim898@gmail.com
}

\begin{abstract}
Abstrack
This article will discuss about the characteristics of sports training that match the characteristic of child development. So hopefully by understanding it, sports training can achieve more optimal results. With the implementation of sports training in accordance with the characteristics of child development it will prevent achievement of peak performance too early. Through the theoretical adjustment between the main biomotor characteristics and the characteristics of motor development, in sepak takraw has been determined the initial age of training is 11 years old daughter and 12 year old son. So with the knowledge of this early age, can facilitate the making of training programs and sports football sepak takraw. So that the optimal achievement in sepak takraw can be achieved.
\end{abstract}

Keywords: Characteristic of Motor Development, Biomotor Characteristics Sepak Takraw

Success in any field is usually a result of planning, hard work, and firm commitment. In addition, in the field of sports, achievements are also the result of training conducted as quickly as possible. The accuracy of this training is the application of one of the principles of the trainer that is indiviualist (Harre, 1981; Foss and Kestian 1998). The training is a repetitive and progressive process, so directing an athlete achieves its optimum performance. Although some trainers seem to be able to develop an exercise program, but it should be noted that the program still need pay attention to the approach and characteristics of the program in accordance with the level of growth and development. For that reason, during a long-term training program, an athlete also experienced a progression during the time period. This will be experienced by the prospective athlete who to get the optimum appearance he should practice since childhood.

However, in fact that many coaches ignore the suitability, this is due to the desire of the coach or the club to become a champion and quickly have the ability as the ability of the stars in various sports such as Michael Jordan, Pate Sampras or others. Such curiosity leads coaches to simply quote the star training program to apply to their trainee children. In fact, children are not small adult people, but have unique characteristics, both physical and physiological, even those abilities will 
develop over time.

In facts,this may also be found in the coaching of the branches of sports around us. In order not to aggravate the situation, and to achieve optimal performance in the future, it is necessary to immediately apply the various principles of human development and growth in the training oftakraw sport.

Through this paper, will be presented about a brief guide in the determination in initiating takraw practice based on the principles of motor development

Many factors can affect less optimal performance of teachers, including team characteristics, organizational justice, and work ethics. The characteristics of a solid or cohesive team are needed in order to produce optimal performance. There is a great teamwork between teachers and other members of the school to smoothen and facilitate work. According to Ancona et al. (2009), the team includes all the characteristics of group work but is interdependent and simultaneously responsible for achieving performance goals. According to Doss (3007: 174), the characteristics of successful teams are six: clear goals, high team member commitment, clarity of roles, mutual respect, communication openness and consistent training or supervision. Previous research results such as Danish et al. (2015) also found that team characteristics that include cohesion, role clarity, goal motivation, and openness to change have a significant effect on performance.

\section{DISCUSSION}

\section{Development Of Long-Term Training Programs}

For a long time, many coaches have suggested starting at an early training in a particular sport (specializing earlier). Some physiologists still hold much of this opinion, even today many coaches have argued that and stated in an exercise program. They also suggest that to get quick results then the training should follow the following points:

$\rightarrow$ emphasis on major energy systems in sports. For sprinter it should be a sprint exercise.

$\rightarrow$ As the characteristics of motion skills, so the athlete should be able to choose an exercise that resembles a true pattern of motion skills.

In fact, laboratory results suggest that specific training results in faster adaptation, directing rapid performance improvements. However, Trainers and athletes do not have to follow such methods, especially the application of the exercises to children and during the process of physical maturity (Bompa, 2000).

If this is done in childhood, then there will be acceleration in achieving peak performance, and doing specific training too early is tantamount to training athletes with high ability but basic or weak foundations. Even the apparent effects are as follows:

$>$ Can lead to unilateral formation, both the development of the body's functional muscle 
Can damage the harmony of physical development with various things that are biological

If it occurs over a considerable length of time, it can lead to overuse

Interfere with the development of social relationships of children, because too concentrated on intensive training

Child motivation may be reduced in the midst of intensive training program due to boredom and less fun. It can even quit the sport before it reaches good biological and physiological maturity. Consequently, a child will not be able to discover how talented he is

\section{Multirateral Development}

It is important for children to form a variety of basic sports skills to help them become versatile athletes before they begin training in a particular sport. This is called multilateral development, and this is the most important principle for childhood training

Multilateral or multi-skill development has been used in some European countries where elementary schools have basic training programs. When the child is trained in such a way, then the chances of the child getting achievement in various sports fields, and will have a strong desire to conduct specification, and will develop the gift better. When children show interest in the development of their talents, we must provide opportunities and encouragement. And it is the time to start forming them into champions.

Figure 1 shows the times to develop athlete's talent for several years. Although age in each sport is different, it shows the importance of a gradual development approach

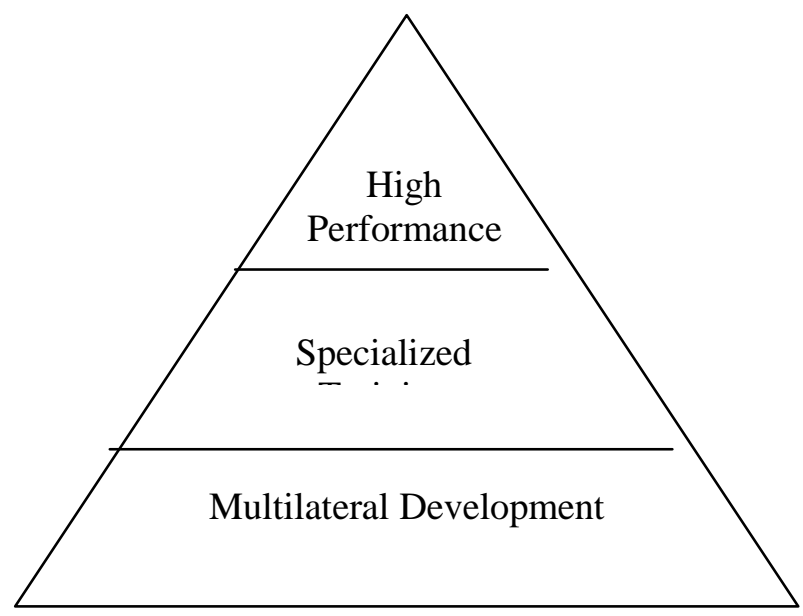

Picture 1. a long-term approach to exercise training. (Bompa, 1999). 
The goal of multilateral development is to improve all the adaptability of children who make up some of the more advanced motor skills and abilities as an adaptation of the exercises, with no stressing as a result of too early Specialization. The development will lead the athlete to be more successful in skills mastery at the next level of development.

Table 1 Comparison between early specialization with multilateral development

\begin{tabular}{|l|l|}
\hline \multicolumn{1}{|c|}{ Early Specialization } & \multicolumn{1}{c|}{ Multilateral Development } \\
\hline $\begin{array}{l}\text { Fast Improvement } \\
\text { age of 15-16 years due to the rapid } \\
\text { adaptation }\end{array}$ & $\begin{array}{l}\text { Slow improvement skills } \\
\text { age of more than } 18 \text { years }\end{array}$ \\
$\begin{array}{l}\text { Inconsistency of appearance in the } \\
\text { competition }\end{array}$ & Has a consistent appearance \\
$\begin{array}{l}\text { When the age of } 18 \text { athletes can get out of } \\
\text { these sports activities }\end{array}$ & Slightly injured \\
Often injured & \\
\hline
\end{tabular}

\section{Specialized Development}

Specialization occurs after the athlete undergoes multilateral development, and when the athlete allows it to be specialized. Specialization is also important to achieve a good performance, this is due to specialization optimizing physical, physiological and technical adaptation

When stepping on the specification, the applied training program should consist of specific, appropriate exercises in each sport branch. Specialization on every sport is also different. Examples of artistic motion, complex motor development, and high flexibility such as gymnastics, diving, and others, athletes should specialize from an early age (Hare, 1982, Bompa, 2000). While for sporting with the conditions of the main biomotor aspects of speed and power, such as soccer, baseball,takraw and volleyball, athletes can begin training in the late childhood. However, specialization can be done only if the athlete has the ability and motor development that suits the needs of the sport.

\section{Understanding Individual Motor Development Characteristics}

Each athlete is different in personality, physical characteristics, social behavior and intellectual capacity. With such conditions, it is necessary in the development of an exercise program to be tailored to each individual's character, so that the training will be more effective. Therefore, trainers should know and be 
able to determine individual differences, such as the level of motor development, the background of training experience, the health status, the level of recourse between training and competition, and the differences caused by gender.

To differentiate the need for athletic training, many trainers differentiate or group athletes with chronological age differences. However, this is less precise, since children of the same chronological age are not necessarily same in their anatomical maturation (Espenschade and Eckert, 1980; Gallahue, D.L., and Ozmun, J.C., 1998). Following will be discussed about the anatomical age, age of biological, and athletic age.

\section{Age of anatomy}

Anatomical age is a few levels of anatomical growth that we can know by identifying some of its characteristics. Anatomical age also shows complex development and growth. Knowing this, the trainer will know how the development of a child's skills and ability to move faster or slower than others. A child whose age more mature anatomically, will be faster in learning his motion skills than an immature child. Although the growth pattern of children looks almost the same, but actually growth varies as a result of environmental influences such as climate, altitude, geomorphology (mountain or flat), and neighborhood (village or city). In areas or countries with hot climates such as Indonesia, children will mature faster in sexually, emotionally and physically (Espenschade and Eckert, 1980; Gallahue, D.L., and Ozmun, JC., 1998). As a result, sports peak performance is faster than countries with a cooler climate. Similarly, children residing in high residence areas will be more effective in sport endurance than those in lowland (Bompa, 2000) For example: Kenyan athletes, many who dominate in long-range running, are due By several generations they have lived high from the sea surface where the oxygen tension is lower. Consequently, they have genetic factors in using oxygen, so they become better than athletes coming from the lowlands (bompa, 2000).

\section{Biological Age}

Biological age is a physiological development of organs and bodies that work in the body that determine the physiological potential of exercise and competition. This classification is very important to be done because the classification of athletes based on chronological age generates a lot of misjudgment, evaluation mistakes and causes the inappropriate action taken by the coach

Two athletes of the same anatomical age with appropriate features such as the height, weight, and development of his muscle, may differ in their biological age. So also with children who look taller and stronger yet certain faster than others. Perhaps, smaller and shorter athletes are more agile. Unlike the anatomical age that can be seen, the development of biological age is not visible, but to find 
out it needs to do some physiological tests.

Without knowing this, it will be very difficult to determine whether the child is capable enough or worthy to perform a particular training program with a certain load.

On the other hand, there are still many trainers who continue to use chronological age in classifying athletes and setting up training programs. Even in the State of Indonesia there is still a lot of competition classification based on age group. Surely for these individual branches would be very detrimental to athletes, but on team sports such as football, and takraw is not so influential as a result of the variations of the team members. And in team sports, success is also influenced by good cooperation.

Table 2 Characteristics of Human Motor Development

\begin{tabular}{|c|c|c|c|c|}
\hline $\begin{array}{c}\text { Development } \\
\text { Stage }\end{array}$ & $\begin{array}{c}\text { Chronological } \\
\text { Age } \\
\text { (year) }\end{array}$ & Phase & Age & $\begin{array}{c}\text { Characteristics of } \\
\text { Development }\end{array}$ \\
\hline $\begin{array}{l}\text { Early } \\
\text { childhood }\end{array}$ & $0-2$ & $\begin{array}{l}\text { New born } \\
\text { Infant } \\
\text { Crawling } \\
\text { Walking }\end{array}$ & $\begin{array}{l}0.30 \text { day } \\
1-8 \text { month } \\
9-12 \text { month } \\
1-2 \text { year }\end{array}$ & $\begin{array}{l}\text { The development of } \\
\text { organs is very fast }\end{array}$ \\
\hline Pres School & $3-5$ & $\begin{array}{l}\text { Small } \\
\text { Medium } \\
\text { Big }\end{array}$ & $\begin{array}{l}\text { 3-4 year } \\
3-5 \text { year } \\
5-6 \text { tahun }\end{array}$ & $\begin{array}{l}\text { The unique } \\
\text { developmental } \\
\text { rhythm in which } \\
\text { there are complex } \\
\text { and important } \\
\text { changes (functional, } \\
\text { behavioral, } \\
\text { personality) }\end{array}$ \\
\hline School years & $6-18$ & $\begin{array}{c}\text { Pre } \\
\text { puberty }\end{array}$ & $\begin{array}{l}\text { 6-11 year } \\
\text { girls } \\
7-12 \text { year } \\
\text { boys }\end{array}$ & $\begin{array}{l}\text { The development of } \\
\text { functional balance of } \\
\text { somer organs } \\
\text { becomes more } \\
\text { efficient }\end{array}$ \\
\hline
\end{tabular}




\begin{tabular}{|c|c|c|c|c|}
\hline & & Puberty & $\begin{array}{l}11-13 \text { year } \\
\text { girl } \\
12-14 \text { year } \\
\text { boys }\end{array}$ & $\begin{array}{l}\text { Rapid development } \\
\text { and growth in the } \\
\text { height, weight and } \\
\text { efficiency of multiple } \\
\text { organs; Sexual } \\
\text { maturity with } \\
\text { changes in attraction } \\
\text { to the opposite sex } \\
\text { and behavior }\end{array}$ \\
\hline & & $\begin{array}{l}\text { Post } \\
\text { puberty } \\
\text { Adolesce } \\
\text { nce }\end{array}$ & $\begin{array}{l}13-18 \text { year } \\
\text { girl } \\
14-18 \text { year } \\
\text { boys }\end{array}$ & $\begin{array}{lr}\text { Proportional } \\
\text { development } \\
\text { relatively is } \\
\begin{array}{l}\text { Development } \\
\text { functional } \\
\text { of organs }\end{array} \\
\end{array}$ \\
\hline Young adult & $19-25$ & Maturity & 19-25 year & $\begin{array}{l}\text { Period of maturity } \\
\text { and functional and } \\
\text { psychological } \\
\text { improvement, } \\
\text { maximizing athletic } \\
\text { and psychological } \\
\text { potential }\end{array}$ \\
\hline
\end{tabular}

\section{Athletic Age}

Based on the discussion above, the trainer often experienced difficulties in determining anatomical and biological age subjectively because the implementation of the tests is also difficult to accurately. As a result, it is difficult to determine whether the child is ready to compete at a higher level. Several national and international organizations have made scientific approaches gained from scientific research in particular in relation to the biological potentials of certain age groups. That way, the organization has been able to determine the age requirement to follow each level of competition, although it is also still much controversy.

Athletic age is the minimum age of an athlete in following a degree of composition. Provision of athletic age can be a guide for the trainer to develop a long-term exercise program. As early as too early the introduction can be avoided, and overall child development in all sports can be done. If we can do this for a few years, therefore, we will be able to become international world champions. 
Tabel 3 Age for International Competition

\begin{tabular}{|l|l|l|l|}
\hline \multirow{2}{*}{ Sport } & \multirow{2}{*}{ Minimum Age } & \multicolumn{3}{|l|}{ Classification of Competitions } \\
\cline { 3 - 4 } & & Junior & Senior \\
\hline Atletic & 14 & 18 & $>19$ \\
\hline Boxing & - & 18 & $>19$ \\
\hline Dayung / Paddle & - & 19 & $>20$ \\
\hline Diving & 14 & - & - \\
\hline Fencing & - & 20 & $>21$ \\
\hline gymnastics & 14 & & \\
Girl & - & 18 & $>20$ \\
Boy & - & 18 & $>20$ \\
\hline Swim & - & 15 & $>16$ \\
\hline Tennis & - & 18 & $>19$ \\
\hline
\end{tabular}

\section{Main Biomotor Characteristics in SepakTakraw Techniques}

Based on the results of the research that has been done by Hakim et al (2007), the biomotor characteristics of eachtakraw technique can be explained as follows.

\section{Technical technique (service)}

The main biomotor components in motion are flexibility, speed and strength. This is in accordance with the results of research that has been done by Nurali and friends (2004), found that the better the degree of flexibility and the speed of the limbs would add to both the initial results, even the accuracy of the mills would also be more accurate (Hanif, A. S., et al., 2005). And, tekong that have better speed capability will look slightly smaller to make mistakes during service.

\section{Rolling smash technique and kedeng}

The main biomotor components in this movement are strength and leg power, speed, flexibility, muscle strength of the legs, stomach, and back. This is also supported by several studies that have been done by (Gani, 2004), which found a significant positive relationship between leg muscle strength, stomach, and back with smash results.

\section{Football technique (bait)}

The main biomotor aspects are the strength of ankle (leg muscle) and flexibility of the legs. With that ability, motion techniques will be better so as to produce a good kick and easy to accept. In addition, a good kinesthetic perception is also required when a feeder performs its duties as a feeder, this kinesthetic perception is required in order for the feed to be produced in accordance with the wishes of the speakers.

The first ball technique

As the results of the research, the reaction speed is a major component that must be owned if you want to have the ability to receive the first ball is good. This 
is due to the fact that the ball coming from the opponent's opponent runs at a very high speed so that the reaction speed is required to keep up with the ball.

\section{Implications at the early age of the training}

From the explanations above, then the theoretical determination of the beginning of age in practicingtakraw can be determined. It is known that the main biomotor aspect in the sport oftakraw is strength, speed and flexibility, according to the characteristics of the development of the child as mentioned before, the early age of soccer takraw practice is the early puberty which is 11 years for the girls, and 12 years for the boys.

\section{CONCLUSION}

The characteristic of motor and growth development is a knowledge that must be known and understood by trainers of achievement sport. This is done for the exercise program is structured according to the characteristics of individual athletes, so that the exercise program is run effectively and efficiently in developing the athlete's ability to optimum performance.

Besides, with such knowledge the trainer can determine the periodization of long-term exercise so that the athletes avoid the achievement of peak performance too early. And the accuracy of starting age of training of each sport is also necessary for injury and disruption in the process of growth and development both physically and mentally can be minimized. It is also for takraw sport.

Through the theoretical adjustment between the main biomotor characteristics and the characteristics of motor development, in takraw has been determined the initial age of training is 11 years old for girls and 12 year old for boys. So with the knowledge of this early age can facilitate the making of training programs andtakraw sport. So that the optimal achievement in takrawsport can be achieved.

\section{REFRENCES}

Bompa, Tudor.O.2000. Total Traing for Young Champions.Unitet States.Human k kenetics

Bompa, T.O. 1999. Periodization: Theory and Methodology of Training. Champaign, IL: Human Kinetics.

David L. Gallahue, John C. Ozmun. 1998. Understanding Motor Development : Infants, Children, Adolescents, Adults. Fourth Edition. United States of America: Mc. Graw Hill Companis.

Espenschade, A., dan Eckert, H. M., 1980. Motor Development Second Edition. Ohio: Charles E. Merrill Publishing Company.

Foss, Merle L., 1998.Physiogical Basis for Exercise and Sport. New York: The McGraw Companies, Inc.

Gani, A. 2004. Hubungan kekuatan otot tungkai dan perut dengan kemampuan smash. Coach Jurnal Ilmu Kepelatihan, 3 (1): 53-67.

Hakim, A. Aziz. 2006. Sepak Takraw: diktat kuliah sepak takraw. 
Hakim, A. Aziz. 2004. Kajian Pendahuluan Tentang Uji Validitas dan Reliabilitas Instrumen Tes Sepak Mula Cabang Olahraga Sepaktakraw. (Skripsi : tidak dipublikasikan).

Hakim, A. Aziz. 2006. Analisis Perolehan angka dalam permainan sepak takraw. Jurnal Pelangi Ilmu. 1 (1): 45-60.

Hakim, A. Aziz, dkk. 2007. Identifikasi sistem energi utama dalam sepak takraw. Surabaya:

Hanif, Sofyan., dkk. 2005. Hubungan Antara Panjang Tungkai dan Daya Tahan Otot Perut Dengan Ketepatan Servis Dalam Permainan Sepaktakraw Pada Siswa SLTP 143 Cilincing. Coach Jurnal Ilmu Kepelatihan, 4 (1): 24-40.

Nurali., 2005. Hubungan kekuatan fleksibilitas dan kekuatan tungkai terhadap hasil sepak mula. Coach Jurnal Ilmu Kepelatihan, 5 (1): 56-70.

Hare, Dietrich. 1982. Principles of Sports Training. Berlin: Sportverlag Berlin.

Pate, dkk. 1984. Scientific Foundation of Coaching. New York: Sounder College Publishing. 